\title{
Yoğun Bakım Ünitelerinden İzole Edilen Acinetobacter Baumannı Suşlarının Direnç Profili: Beş Yıllık Çalışma
}

\author{
(iD) Hülya Duran¹, (iD) Nihan Çeken², (iD) Bülent Atik ${ }^{3}$ \\ ${ }^{1}$ Uzm. Dr., İsmail Fehmi Cumalıoğlu Şehir Hastanesi, Mikrobiyoloji Laboratuvarı, Tekirdağ, Türkiye. \\ ${ }^{2}$ Uzm. Dr., Balıkesir Devlet Hastanesi Tıbbi mikrobiyoloji laboratuvarı, Balıkesir, Türkiye. \\ ${ }^{3}$ Dr. Öğr. Üyesi, Balıkesir Üniversitesi Tıp Fakültesi, Anesteziyoloji ve Reanimasyon Anabilim Dalı, Balıkesir, Türkiye. \\ $\ddot{0} z$
}

Yoğun Bakım Ünitelerinden Izole Edilen Acinetobacter Baumannı Sușlarının Direnç Profili: Beș Yıllık Çalıșma

Amaç: Antibiyotik direnci son yıllarda tüm dünyada artış göstermiștir. Bu durum özellikle yoğun bakım ünitelerinde (YBÜ) yatan hastalarda ciddi sağlık problemi olușturmaktadır. Acinetobacter baumannii YBÜ'de yatan hastalarda çoklu ilaç dirençli enfeksiyonların önemli bir nedeni haline gelmiştir. Bu çalıșmanın amacı YBÜ’den izole edilen A.baumannii suşlarının direnç oranlarını saptamaktır.

Gereç ve Yöntem:2015-2019 yılları arasında YBÜ’lerden mikrobiyoloji laboratuvarına gönderilen çeșitli örneklerden izole edilen A.baumannii sușları çalıșmaya dahil edilmiştir. Bakteri tanımlaması ve antibiyotik duyarlılık testleri konvansiyonel yöntemler ve otomatize sistemler kullanılarak yapılmıștır.

Bulgular: Toplam 773 A.baumannii suşu çalışmaya dahil edilmiștir. Suşların izole edildiği örnekler arasında endotrakeal aspirat örnekleri ilk sırada (\%65.3) saptanmıștır. İzole edilen A.baumannii sușlarının en dirençli olduğu antibiyotik grubu karbapenemler (\%96.5) olarak bulunmuştur. Siprofloksasine \%96.1, netilmisine \%89.8, gentamisine \%88, amikasine \%66 ve trimetoprim-sülfametoksazole \%67.7 direnç tespit edilmiştir. Ayrıca, direnç oranlarının yıllar içinde arttığı gözlenmiştir.

Sonuç: A.baumannii suşlarının antimikrobiyal ajanlara direnç oranları hastaneler arasında farklılık gösterdiğinden her hastane belirli aralıklarla kendi antibiyotik direnç profilini gözden geçirmeli ve antibiyotik kullanım politikalarını belirlemelidir. Ayrıca geniş spektrumlu antibiyotiklerin yaygın kullanımının kısıtlanarak direnç gelișiminin önlenmesi hedeflenmelidir.

Anahtar Kelimeler: Yoğun Bakım Ünitesi, Acinetobacter Baumannii, Antibiyotik Direnci

\section{Abstract}

\section{Resistance Profile of Acinetobacter Baumannii Strains Isolated from Intensive Care Units: A Five-Years Study}

Objective: In recent years antibiotic resistance has risen worldwide. It poses a serious health threat to intensive care unit (ICU) patients. Acinetobacter baumannii has become an important cause of multidrug resistant infections, especially patients in ICU. The aim of this study was to screen antibiotic resistance profiles in A.baumannii strains isolated from ICU.

Methods: In this study, A.baumannii strains isolated from clinical samples sent from ICUs to microbiology laboratory between 20152019, were evaluated. Bacterial identification and antibiotic susceptibility tests were performed using conventional methods and automated systems.

Results: A total of 773 A.baumannii isolates were included in the study. Among the samples in which strains were isolated, endotracheal aspirate samples was found first (65.3\%). A.baumannii strains showed the highest resistance to carbapenems (96.5\%). Ciprofloxacin $96.1 \%$, netilmicin $89.8 \%$, gentamicin $88 \%$, amikacin $66 \%$ and trimethoprim-sulfamethoxazole $67.7 \%$ resistance were detected. Also, the resistance rates have increased over the years.

Conclusion: As a result, the resistance rates of A.baumannii strains to antimicrobial agents differ between hospitals, each hospital should periodically review its own antibiotic resistance profile and determine their antibiotic use policies. The usage of broad-spectrum antibiotics should be restricted due to high resistance rates.

Keywords: Intensive Care Unit, Acinetobacter Baumannii, Antibiotic Resistance

Nasıl Atıf Yapmalı: Duran H, Çeken N, Atik B. Yoğun Bakım Ünitelerinden İzole Edilen Acinetobacter Baumannıı Sușlarının Direnç Profili: Beș Yılık Çalıșma.MKÜ Tıp Dergisi. 2021;12(44):199-204. https://doi.org/10.17944/mkutfd.941102 


\section{Giliș}

Acinetobacter baumannii özellikle yoğun bakım ünitesinde (YBÜ) yatan hastalarda pnömoni, üriner sistem enfeksiyonu, menenjit, yumuşak doku enfeksiyonu ve bakteriyemi gibi birçok enfeksiyona neden olabilen önemli bir fırsatçı patojendir $(1,3)$. Uzun süre hastanede yatış, geniş spektrumlu antibiyotik kullanımı ve mekanik ventilatör ya da kateter gibi invaziv ișlemlerin uygulanması A.baumannii'ye bağlı enfeksiyonların oluşmasında risk faktörleri arasında sayılabilir $(4,5)$. Ileri medikal destek gereken hastaların sayısının artması bu enfeksiyonların insidansının artmasına neden olmuștur (5). A.baumannii sușlarının birçok antibiyotiğe doğal dirençli olmaları ve kısa sürede kazanılmış direnç geliștirebilmeleri, tüm dünyada tedavi politikalarında ciddi problemler olușturmakta, ayrıca hastanede yatış süresinin uzaması, tedavi maliyetleri ve mortalitenin artması gibi pek çok sorunu da beraberinde getirmektedir $(6,7,8)$.

Dünya Sağlık Örgütü antibiyotiklere karșı direncin toplumdaki ve sağlık kuruluşlarındaki sürveyansının yapıımasının direncin azaltılmasında önemli olduğunu vurgulamıștır (9). Bu çalıșma, YBÜ'de yatan hastalardan izole edilen A.baumannii sușlarının antibiyotiklere direnç durumunun yıllar içindeki değișimini saptamak ve tedaviye yol göstermek amacıyla yapılmıștır.

\section{GEREÇ VE YÖNTEM}

Bu çalıșmada, Ocak 2015 - Aralık 2019 tarihleri arasında 2. basamak hastane olan 400 yataklı Balıkesir Devlet hastanesinde 16 yataklı birinci basamak, 17 yataklı ikinci basamak ve 18 yataklı üçüncü basamak YBÜ'lerinde yatan hastalara ait klinik örnekler retrospektif olarak incelenmiștir. Hastalara ait endotrakeal aspirat (ETA), kan, idrar, yara, balgam ve kateter ucu örnekleri değerlendirilmiş ve A.baumannii üremesi saptanan örnekler çalıșmaya dahil edilmiștir. Kan kültürü örnekleri BacT/ALERT 3D (bioMérieux, Fransa) (Ocak 2016-Ağustos 2018) ve Render-BC128 (Çin) (Eylül 2018-Aralık 2019) otomatize kan kültür sisteminde takip edilmiștir. Tüm örnekler kanlı agar ve Eosin Methylene Blue (EMB) agara ekim yapılarak $37^{\circ} \mathrm{C}$ 'de $24-48$ saat inkübe edilmiștir. İzole edilen suşlar konvansiyonel yöntemler (koloni morfolojisi, gram boyama, oksidaz testi, karbonhidrat kullanımı) ve BD Phoenix 100 otomatize identifikasyon sistemi (BD Phoenix System, Beckton Dickinson, ABD) ile tanımlanmıștır. İzolatların in-vitro antibiyotik duyarlılıkları European Committee on Antimicrobial Susceptibility Testing (EUCAST)10 kriterleri temel alınarak Phoenix TM 100 otomatize identifikasyon sistemi (BD Phoenix System, Beckton Dickinson, ABD) kullanılarak tespit edilmiștir. Bu çalıșmada amikasin, gentamisin, netilmisin, karbapenemler (imipenem, meropenem), trimetoprim-sülfametoksazol (TMP-SXT) ve siprofloksasin değerlendirilmiş, kolistin EUCAST kriterlerine göre çalıșılamadığından değerlendirme dıșı bırakılmıștır. Aynı hastaya ait aynı klinik örnekte üreyen ilk izolat çalışmaya dahil edilmiştir.

\section{BULGULAR}

Beș yıllık süreçte, 773 A.baumannii suşu izole edilmiş ve değerlendirmeye alınmıștır. YBÜ'den gönderilen klinik örneklerde A.baumannii üreme sıklığı \%10.5 olarak tespit edilmiştir. Sușların izole edildiği örnekler arasında ETA örnekleri ilk sırada (\%65.3) saptanmıștır (Tablo 1).

\begin{tabular}{|c|c|c|c|c|c|c|c|}
\hline \multirow{2}{*}{ Örnek } & \multirow{2}{*}{$\begin{array}{c}2015 \\
n=110\end{array}$} & \multirow{2}{*}{$\begin{array}{c}2016 \\
n=158\end{array}$} & \multirow{2}{*}{$\begin{array}{c}2017 \\
n=177\end{array}$} & \multirow{2}{*}{$\begin{array}{c}2018 \\
n=177\end{array}$} & \multirow{2}{*}{$\begin{array}{c}2019 \\
n=151\end{array}$} & \multicolumn{2}{|c|}{ Toplam } \\
\hline & & & & & & $\mathrm{n}=773$ & $\%$ \\
\hline ETA & 82 & 104 & 109 & 104 & 106 & 505 & 65. \\
\hline Kan & 8 & 19 & 26 & 25 & 9 & 87 & 11.3 \\
\hline İdrar & 10 & 10 & 17 & 15 & 16 & 68 & 8.8 \\
\hline Yara & 10 & 16 & 10 & 12 & 9 & 57 & 7.4 \\
\hline Balgam & 0 & 6 & 9 & 18 & 11 & 44 & 5.7 \\
\hline Kateter ucu & 0 & 3 & 6 & 3 & 0 & 12 & 1.5 \\
\hline
\end{tabular}

Laboratuvarımıza YBÜ'den gönderilen ETA örneklerinin \%26.3'ünde, balgam örneklerinin \%21.4'ünde, kateter ucu örneklerinin \%18.2'sinde, yara örneklerinin \%18'inde, kan örneklerinin \%3.4'ünde ve idrar örneklerinin \%3'ünde A.baumannii ürediği görülmüștür.

İzolatların en dirençli olduğu antibiyotik grubu karbapenemler (\%96.5) olarak saptanmıștır (Tablo 2). Yıllara göre direnç oranlarına baktığımızda 2015 ve 2016 yılında en yüksek direnç siprofloksasine karșı iken diğer yıllarda karbapenemlere karşı bulunmuștur (Sekil 1). Tüm izolatların en duyarlı olduğu antibiyotiklerin yakın direnç oranlarıyla amikasin (\%66) ve TMP-SXT (\%67.7) olduğu görülmüștür. Yıllar içindeki değișime bakınca çalıșmanın ilk üç yılında amikasinin, sonraki iki yılda ise TMP-SXT'nun en duyarlı ajan olduğu tespit edilmiștir.

\begin{tabular}{|c|c|c|c|c|c|c|c|}
\hline \multirow{2}{*}{ Antibiyotik } & \multirow{2}{*}{$\begin{array}{c}2015 \\
n=110\end{array}$} & \multirow{2}{*}{$\begin{array}{c}2016 \\
n=158\end{array}$} & \multirow{2}{*}{$\begin{array}{c}2017 \\
n=177\end{array}$} & \multirow{2}{*}{$\begin{array}{c}2018 \\
n=177\end{array}$} & \multirow{2}{*}{$\begin{array}{c}2019 \\
n=151\end{array}$} & \multicolumn{2}{|c|}{ Toplam } \\
\hline & & & & & & $(n)=773$ & $\%$ \\
\hline Amikasin & 33.6 & 61.4 & 44.6 & 87 & 94.7 & 510 & 66 \\
\hline Gentamisin & 65.4 & 91.1 & 92.7 & 87.6 & 96 & 680 & 88 \\
\hline Netilmisin & 90.9 & 82.9 & 89.8 & 88.7 & 97.4 & 694 & 89.8 \\
\hline Karbapenemler & 92.7 & 96.2 & 98.3 & 96 & 98 & 746 & 96.5 \\
\hline TMP-SXT* & 40.9 & 64.6 & 67.8 & 70.1 & 87.4 & 523 & 67.7 \\
\hline Siprofloksasin & 99.1 & 97.5 & 93.8 & 94.9 & 96.7 & 743 & 96.1 \\
\hline
\end{tabular}




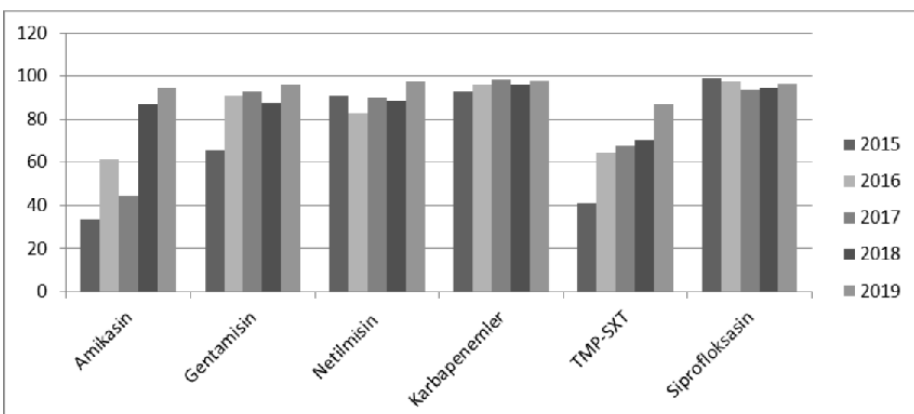

Sekil 1. İzole edilen A.baumanni sușlarının antibiyotik direnç oranlarının yıllara göre değișimi

A.baumannii suşlarının izole edildiği örneklere göre direnç oranlarını değerlendirdiğimizde, ETA ve balgam örneklerinde en yüksek direnç karbapenemlere karşı saptanırken idrar, kan ve yara örneklerinde siprofloksasine karşı tespit edilmiştir. Kateter ucu örneklerinden izole edilen suşlarda ise her iki ajana karșı eșit direnç görülmüștür. ETA, idrar, yara ve balgam örneklerinde en az duyarlı olduğu antibiyotik amikasin olarak bulunurken kan ve kateter ucu örneklerinde TMP-SXT olduğu saptanmıștır (Tablo 3).

\begin{tabular}{|c|c|c|c|c|c|c|c|c|}
\hline \\
Tablo 3: izole edilen A. baumanni suşların In antibiyotik direnç \\
oranların In örneklere göre değisimi (\%)
\end{tabular}

\section{TARTIȘMA}

Tüm dünyada dirençli A.baumannii sușlarının neden olduğu enfeksiyonların sıklığı artmakta ve yüksek mortaliteye neden olmaktadırlar. Özellikle YBÜ'de sık ve uygunsuz antibiyotik kullanımı bu enfeksiyonların oluşumuna zemin hazırlamaktadır (11). Barış ve ark. 12 YBÜ'de yatan hastalardan gönderilen örneklerde Acinetobacter spp. türlerinin üreme sıklığını \%12.7 olarak saptamıșlardır. Çalıșmada da bu oranın \%10.5 olduğu görülmüștür. Üreme saptanan örneklerin dağılımı incelendiğinde her yıl en fazla üreme ETA örneklerinde tespit edilmiş ve çalışmalarla uyumlu bulunmuștur $(6,13,17)$.

Karbapenemler, A.baumannii enfeksiyonlarının tedavisinde kullanılan en önemli geniş spektrumlu antibiyotiklerdir. Fakat dünya genelinde karbapenemlere direnç gittikçe artmakta ve tedavi seçeneklerini kısıtlamaktadır $(14,18)$. Yurt dışından yapılan çalıșmalarda A.baumannii izolatlarında karbapenem direnci \%2.9-93.5 gibi geniş bir aralıkta bildirilmektedir (9). Ülkemizde ise farklı yıllarda yapılmış çalıșmalara baktığımızda; Cesur ve ark. 2010-2012 yılları arasında imipeneme \%94, meropeneme \%90, Doruk ve ark. 2009 yılında \%28.6, 2010 yılında \%33.3, 2011-2013 yıllarında \%100, Tümtürk ve ark. 2014 yılında \%90.7, 2015 yılında \%86.4, 2016 yılında \%93.2, 2017 yılında \%95.9, Uğur ve ark. imipenem ve meropeneme sırasıyla 2015 yılında \%98 ve \%99, 2016 yılında \%95 ve \%96, 2017 yılında \%92 ve \%94 oranında direnç bildirmișlerdir $(5,7,14)$ Doruk ve ark'nın 2009-2010 yıllarında saptadıkları direnç göz ardı edilirse dört çalıșmada da neredeyse \%90'ın üzerinde ciddi direnç görülmüștür (5). Bu çalıșmada beș yılda ortalama \%96.5 direnç tespit edilmiş, en düșük saptandığı 2015 yılında bile \%92.7 olarak bulunmuş ve bu oran yıllar içinde de artarak \%98'e ulașmıștır. Ayrıca izolatların tamamı değerlendirildiğinde en dirençli oldukları antimikrobiyal grubu olarak karbapenemler saptanmış, sadece 2015 ve 2016 yılında direnç sıralamasında ikinci sırada yer aldıkları görülmüștür.

Yukarıda bildirilen oranlara bakılınca ülkemizde A.baumannii sușlarında karbapenem direncinin en az on yıldır problem olduğu ve yüksek seyrettiği görülmektedir. Diğer yandan karbapenem direncinin hasta mortalitesini 3-4 kat arttırdığı bildirilmektedir (19). Bu durum hastanelerimizde $A$. baumannii suşlarında karbapenem direncine acil çözüm bulmamız gerektiğini, dirençli izolatlarla kolonizasyonun önüne geçemezsek hastalar için durumun daha da kötüleșeceğini ortaya koymaktadır.

Şafak ve ark.'nın bu çalıșma aynı ilde bulunan diğer merkezde 2010-2016 yılları arasında yaptığı çalıșmada A.baumannii suşlarında 2010 yılında imipeneme \%60.8, meropeneme \%78.5 direnç tespit etmișler ve bu oranın yıllar içinde artarak 2015 yılında \%93.6, 2016 yılında ise \%96.2'ye ulaştığını saptamıșlardır (20). Bu çalıșma ile ortak olan yıllarda saptanan bu oranlar bu çalıșmada bulunan oranlar ile hemen hemen aynıdır. Buradan hareketle ilimiz için karbapenem direncinin son 9 yılda ciddi şekilde artarak çok yüksek boyutlara ulaştığını söyleyebiliriz.

A.baumannii suşları, florokinolonlar ve aminoglikozitler gibi geniş spektrumlu diğer antibiyotiklere de hızla direnç geliștirmektedirler (21). Yıldız ve ark. 2014-2015 yılları arasında erișkin YBÜ'den izole ettikleri A.baumannii izolatlarında siprofloksasine \%98.8, levofloksasine \%98.2 oranında direnç tespit etmișlerdir (22). Bu çalıșmada kinolon grubundan sadece siprofloksasin değerlendirilmiș ve \%96.1 direnç oranıyla karbapenemlerden sonra en yüksek dirence sahip ikinci ilaç olduğu görülmüștür. 2015 ve 2016 yıllarında da A.baumannii sușlarının en az duyarlı olduğu ajan olarak bulunmuștur. Direncin yıllar içindeki değişimine baktığımızda 2015 yılında yaklaşık \%100 direnç varken bu oran 2018 yılına kadar azalmıș sonra tekrar artışa geçmiștir. Bununla beraber idrar ve kateter ucu örneklerinden izole edilen sușların tamamının, 
yara örneklerinden izole edilenlerin ise tamama yakınının siprofloksasine dirençli olduğu görülmüștür. Siprofloksasinin yatan hastalarda sık kullanımının saptadığımız yüksek direnç oranlarına katkı sağladığını düşünmekteyiz.

Enfeksiyon hastalıklarında gerek tedavi başarısını arttırmak gerekse direnç gelișiminin önlenmesi ya da azaltılması amacıyla kombine antibiyotik kullanımı önerilmektedir (23). Aminoglikozitler kombine tedavide sık tercih edilen ajanlardandı (24). Calıșmada izole ettiğimiz sușlarda amikasine karșı yıllar içinde dramatik bir direnç artıșı saptanmıștır (2015 \%33.6-2019 \%94.7). Gentamisinde de amikasin kadar olmasa da benzer șekilde bir artış gözlenmiștir. Netilmisinde direncin \%90 civarında dalgalı seyrettiği ve her yıl en yüksek dirence sahip üçüncü antibiyotik olduğu tespit edilmiştir. Bu sonuç tedavide amikasin ve gentamisinin yıllar içinde daha çok tercih edilir hale geldiğini ortaya koymaktadır.

Son yıllarda özellikle YBÜ'de gözlenen çoklu ilaca dirençli (MDR) A.baumannii enfeksiyonlarının yayılımı tüm dünyada endișeye neden olmaktadır. Çalıșmalarda YBÜ'den izole edilen A.baumannii suşlarının \%30'dan fazlasının sıklıkla florokinoIonlar ve karbapenemleri içeren en az üç antibiyotik sınıfına dirençli olduğu bildirilmektedir (25-27). Yaptığımız çalıșmada bu oranın çok çok daha yüksek olduğu saptanmıștır. 2019 yılında izole ettiğimiz sușlarda değerlendirdiğimiz tüm antibiyotiklere yaklașık \%90'ın üzerinde korkunç bir direnç tespit edilmiștir. Bu durum bize hastanemizde akılcı antibiyotik kullanımına daha fazla önem vererek tedavi politikalarına ciddi düzenlemeler getirmemiz gerektiğini göstermektedir.

Çalıșmada A.baumannii sușlarının en duyarlı olduğu antibiyotik TMP-SXT olarak saptanmıștır. Fakat bu antibiyotiğe de yıllar içinde ciddi direnç geliștiği 2019 yılında \%90’a yaklaștığı gözlenmiștir. Çelik ve ark. yaptıkları çalıșmada A.baumannii sușlarında kolistinden sonra en duyarlı ajanı TMP-SXT olarak saptamıșlardır (28). Bununla beraber Dursun ve ark. Bu çaIıșmanın aksine direncin yıllar içinde azaldığını tespit etmişlerdir (29). Direnç problemi, klinisyenlerin geleneksel antibiyotik kombinasyonları dışında, eski antibiyotiklerin yer aldığı kombinasyon tedavilerini kullanmalarına neden olmuștur. Saptadığımız direnç hastanemizde TMP-SXT'nin A.baumannii enfeksiyonlarında kombine tedavide sık kullanılan bir ajan olduğunu, direncin buna bağlı olarak arttığını düșündürmektedir.

\section{SONUC}

Tüm bu sonuçları değerlendirdiğimizde antimikrobiyalleri seçerken ve kullanırken dikkatli davranmak zorunda olduğumuzu görmekteyiz. Çoklu ilaç direncine sahip suşların hastane içerisinde yayılımının ve varolan sușların daha dirençli hale gelmesinin önlenmesi için in-vitro duyarlılık paternleri sürekli takip edilerek uygunsuz antibiyotik kullanımı engellenmeli, etkin temizlik prosedürleri uygulanmalı, geniş spektrumlu ilaçların kullanımı kısıtlanmalıdır.

\section{BILDIRIMLER}

Değerlendirme

Dış danışmanlarca değerlendirilmiștir.

Çıkar Çatıșması

Yazarlar bu makale ile ilgili herhangi bir çıkar çatıșması bildirmemișlerdir.

Finansal Destek

Yazarlar bu çalıșma sırasında herhangi bir finansal destek kullanmamıșlardır.

Etik Beyan

Bu çalıșma için Balıkesir Üniversitesi Tıp Fakültesi Klinik Araștırmalar Etik Kurulundan 19.08.2020 tarih ve 2020/134 sayılı yazı ile izin alınmış olup Helsinki Bildirgesi kriterleri göz önünde bulundurulmuștur.

\section{KAYNAKLAR}

1. Liu Q, Li W, Du X, Li W, Zhong T, Tang Y, Feng Y, et al. Risk and prognostic factors for multidrugresistant Acinetobacter baumannii complex bacteremia: a retrospective study in a Tertiary Hospital of West China. PLoS ONE 2015;10(6):1-13. https://doi.org/10.1371/journal.pone.0130701

2. Çerçioğlu D, Cesur S, Hatipoğlu ÇA, Yıldırım M, Çelik H, Kınıklı $S$, ve ark. Intratekal kolistinle başarıyla tedavi edilen çoğul dirençli Acinetobacter baumannii'ye bağlı nozokomiyal menenjit. Klimik Derg 2017;30(3):155-7. https://doi. org/10.5152/kd.2017.38

3. Gazel D, Ekși F, Azzawi S, Güneș I, Turan E. Acinetobacter baumannii izolatlarında kolistin heterodirencinin araştııılması. ANKEM Derg 2019;33(3):114-120. https://doi. org/10.5222/ankem.2019.114

4. Uwingabiye J, Lemnouer A, Roca I, Alouane T, Frikh M, Belefquih B, et al. Clonal diversity and detection of carbapenem resistance encoding genes among multidrug-resistant Acinetobacter baumannii isolates recovered from patients and environment in two intensive care units in a Moroccan hospital. Antimicrob Resist Infect Control 2017;6(99):1-9. https://doi.org/10.1186/s13756-017-0262-4

5. Doruk S, Köseoğlu HI, Yenişehirli G, Etikan I, Sağlam DA, Yılmaz A, ve ark. Multidrug resistance among A.baumannii isolates from intensive care unit: a four years retrospective study. Turkiye Klinikleri Arch Lung 2016;17(2):15-20. https:// doi.org/ 10.5336/archlung.2015-49146

6. Uğur M, Genç S. Yoğun bakım ünitelerinden izole edilen Acinetobacter baumannii ve Pseudomonas aeruginosa suşlarının üç yıllık direnç profili. J Turk Soc Intens Care 2019; 17:130-137. https://doi.org/10.4274/tybd.galenos.2018.94103 
7. Tümtürk A, Tekçe AY, Şanal L. Nozokomiyal infeksiyon etkeni Gram negatif bakterilerde karbapenem direnç oranları: Üçüncü basamak bir hastaneden retrospektif bir çalıșma. Ortadogu Tıp Derg 2019;11(4):422-426. https://doi. org//10.21601/ortadogutipdergisi.516673

8. Celiloğlu C, Tolunay O, Çelik T, Sucu A, Yurtçu E, Çelik Ü. Çocuk yoğun bakım ünitesindeki hastane enfeksiyonlarının değerlendirilmesi. J Pediatr Inf 2017;11(3):129-134. https:// doi.org/10.5578/ced.64028

9. Coşkun US. Karbapenem dirençli Acinetobacter baumannii izolatlarında antibiyotik direncinin araştırılması. ANKEM Derg 2018;32(2):37-44. https://doi.org/10.5222/ankem.2018.037

10. European Committee on Antimicrobial Susceptibility Testing. Breakpoint tables for interpretation of MICs and zone diameters Version 9.0, http://www.eucast.org (erişim tarihi: 20.05.2020)

11. Şahin AR, Yıldız BT, Aktemur A, Topal B, Nazik S, Ateș S. Bir üniversite hastanesi noroloji yoğun bakım ünitesinde gelişen enfeksiyonların değerlendirilmesi. J Contemp Med 2019;9(1):43-47. https://doi.org/10.16899/gopctd.481366

12. Barış A, Bulut ME, Öncül A, Bayraktar B. Yoğun bakım ünitelerinde yatan hastalara ait klinik izolatların tür dağılımı ve antibiyotik duyarlılıkları. J Turk Soc Intensive Care 2017;15(1):21-7. https://doi.org/10.4274/tybdd.55707

13. Şahin AR, Doğruer D, Nazik S, Aktemur A, Öksüz H, Aral M, ve ark. Hastane kökenli patojenlerde artan antimikrobiyal direnç sorunu: Acinetobacter baumannii. Online Türk Sağ Bil Derg 2019;4(2):156-169. https://doi.org/10.26453/otjhs.462304

14. Cesur S, Irmak H, Yalçın AN, Berktaş M, Baysan BÖ, Kınıklı S, ve ark. Yoğun bakım ünitesinde yatan hastaların çeșitli kültür örneklerinden izole edilen Acinetobacter baumannii suşlarının antibiyotik duyarlıııkları. Ortadoğu Tıp Derg. 2017;9(2):51-5. https://doi.org/10.21601/ortadogutipdergisi.291062

15. Kapoor K, Jain S, Jajoo M, Dublish S, Dabas V, Manchanda V. Risk factors and predictors of mortality in critically ill children with extensively drug resistant Acinetobacter baumannii infection in a pediatric intensive care unit. Iran J Pediatr 2014;24(5):569-574.

16. Eroğlu C, Ünal N, Karadağ A, Yılmaz H, Acuner IÇ, Günaydın M. Çeșitli klinik örneklerden 2006-2011 yılları arasında izole edilen Acinetobacter türleri ve antibiyotik duyarlılıkları. Turk Hij Den Biyol Derg 2016;73(1):25-32. https://doi.org/10.5505/ TurkHijyen.2016.68915

17. Telli M, Eyigör M, Korkmazgil B, Aydın N, Atalay MA. Acinetobacter spp. klinik izolatlarında karbapenem direncinin moleküler epidemiyolojisi. Türk Mikrobiyol Cem Derg 2017;47(4):190-196. https://doi.org/10.5222/TMCD.2017.190
18. Demirci M, Yiğin A, Demir C. Karbapeneme dirençli Acinetobacter baumannii sușlarında OXA tipi karbapenemaz genlerinin dağılımının gerçek zamanlı polimeraz zincir reaksiyonu yöntemiyle incelenmesi. Klimik Derg 2019;32(2):123-6. https://doi.org/10.5152/kd.2019.29

19. Spellberg B, Bonomo RA. Combination therapy for extreme drug resistant (XDR) Acinetobacter baumannii: ready for prime-time? Crit Care Med 2015;43(6):1332-1334. https://doi. org/10.1097/CCM.0000000000001029

20. Safak B, Kılınç O, Tunç N. Klinik örneklerden izole edilen Acinetobacter baumannii sușlarının antibiyotik duyarlııı oranlarının incelenmesi (2010-2016). FLORA 2016;21(2):77-81.

21. Sezer BE, Doğan M, Aldağ ME, Tülük G. Kolistin dirençli Acinetobacter baumannii tedavisinde sıra dıșı bir antibiyotik kombinasyon tedavisi: trimetoprim-sülfametoksazol ve kolistin kombinasyonu. ANKEM Derg 2017;31(1):32-39. https://doi.org/10.5222/ankem.2017.032

22. Yıldız I, Bayır H, Küçükbayrak A, Yoldaş H, Balcı M, Erkuran MK, ve ark. Acinetobacter infection and resistance profile of intensive care units in a city of Northwestern Anatolia. Acta Med Anatol 2016;4(3):98-100. https://doi.org/10.5505/ actamedica.2016.52714

23. Alada DM, Altoparlak Ü, Coșkun MV. Çeşitli antibiyotik kombinasyonlarının Acinetobacter sușları üzerine in vitro etkinliğinin araştırılması. ANKEM Derg 2017;31(1):23-31. https://doi.org/10.5222/ankem.2017.023

24. Şirin MC, Ağuş N, Yılmaz N, Bayram A, Hancı SY, Şamlıoğlu $P$, ve ark. Yoğun bakım ünitelerinde yatan hastaların kan kültürlerinden izole edilen mikroorganizmalar ve antibiyotik duyarlılıkları. Turk Hij Den Biyol Derg. 2017;74(3):269-278. https://doi.org/10.5505/TurkHijyen.2017.94899

25. Gözalan A, Ünaldı Ö, Kırca F, Çöplü N, Müderris T, Açıkgöz ZC, ve ark. Yoğun bakım ünitelerinde kan dolașımı enfeksiyonu etkeni karbapenem dirençli Acinetobacter baumannii izolatlarının moleküler yöntemlerle karakterizasyonu. Turk Hij Den Biyol Derg, 2020;77(1):15-24. https://doi.org/10.5505/ TurkHijyen.2019.53323

26. Vural DG, Durupınar B. karbapenem dirençli Acinetobacter baumannii klinik izolatlarında sınıf $D$ beta laktamaz varlığının araștırılması. Türk Mikrobiyol Cem Derg 2016;46(4):181-187. https://doi.org/10.5222/TMCD.2016.181

27. Şahintürk H, Özdemirkan A, Kılıç F, Özalp O, Arslan H, Zeyneloğlu P, ve ark. Cerrahi yoğun bakım hastalarında çoklu ilaç dirençli enfeksiyonların mortalite üzerine etkisi. J Turk Soc Intensive Care 2018;16:58-63. https://doi.org/10.4274/ tybd.73636

28. Çelik N, Çelik O, Aslan H, Savaş G, Yılmaz Sí. Erzurum Bölge Eğitim ve Araştırma Hastanesi'nde tespit edilen Acinetobacter baumannii suşlarının antibiyotik direnç oranları. Sakarya Tıp Derg 2017;7(4):229-234. 
29. Dursun A, Özsoylu S, Kılıç H, Kılıç AU, Akyıldız BN. Çocuk yoğun bakım ünitesinde yatan hastalardan izole edilen Pseudomonas aeruginosa, Klebsiella pneumoniae ve Acinetobacter baumannii sușlarının antibiyotik duyarlılıkları. Turk J Intensive Care 2018;16:109-14. https://doi.org/10.4274/ tybd.63825. 